\title{
EVIDENCE OF THE MIDDLE MIOCENE PARATETHYS TRANSGRESSION FROM JURKOWICE-BUDY SITE (SE HOLY CROSS MOUNTAINS, POLAND)
}

\author{
OLGA REUTT', PIOTR WESTPHAL ${ }^{2}$
}

\begin{abstract}
Identifying ancient shores may provide valuable information concerning sea-level fluctuations and environmental changes, since they serve as a reliable marker of palaeoshorelines. This paper deals with deposits that display features of a nearshore zone. In the Jurkowice-Budy quarry (southern slopes of the Holy Cross Mountains) a sequence of clastic sediments and littoral structures linked to the transgression of the Paratethys Sea in the middle Miocene has been recognised. The discovery of bio-erosional assemblages (borings of lithophags) in Devonian limestone boulders helped to determine the littoral nature of the examined deposits and to layout a palaeocliff wall. The samples of sandy sediments were analysed by sieving procedure and interpreted using statistical parameters calculated by graphic and moment methods. Moreover, morphometric analysis of gravels and analysis of mineralogical composition under binocular microscope were performed. The results showed well-developed beach assemblages composed of pebbles, coarse-to-medium sands and silty sands derived from eroded Cambrian strata (sandstones) located to the north of the study site.
\end{abstract}

Key words: Paratethys, middle Miocene, palaeocliff, gravel beaches, Holy Cross Mountains

\section{Introduction}

Contemporary sandy beaches fringe about $20 \%$ of the world's coastline, while gravel beaches represent another $10 \%$ or so (Davidson-Arnott et al. 2019), particularly at high latitudes, where coastal sediments inherit sedimentary features of glacial environment. Gravel beaches are also present at lower latitudes and are associated with tectonic coasts where steep river systems deliver coarsegrained material to the shore or near eroding cliffs (Finkl, Makowski 2019). Beside climate itself, hinterland geology, too, plays also an important role in formation of the beach systems, since source rocks are able to supply large amounts of sediments to the coast. Ancient coastal system consisting of beaches and cliffs were prone to massive erosion and therefore their presence in the stratigraphic record is limited, but rapid transgression is one of the mechanisms that may help preserve their three-dimensional relief (Johnson 1988).

Such a case has been recorded in SE Poland (specifically, the southern margin of the Holy Cross Mountains) at numerous sites that have been the subject of intense studies by Radwański (1965,
$1967,1969,1973)$, who described in detail various species of rock-borers and distinguished different littoral structures linked to the Paratethys transgression, including the ones in the Jurkowice-Budy quarry. His discoveries led to a vast reconstruction of middle Miocene palaeogeography on the southern slopes of the Holy Cross Mts.

The Paratethys was a large epicontinental sea formed in the early Oligocene as a relic of the Tethys. The central part (the Central Paratethys Sea) extended over an area between the Eastern Alps, Dinarides and Carpathians (Kováč et al. 2007), and in the early Badenian (middle Miocene) it covered almost the entire Carpathian Foredeep (SE Poland) (Fig. 1) and became a peripheral foreland basin. The palaeo-environmental conditions of the Paratethys varied considerably under the influence of temporary connections with the Mediterranean and the Indo-Pacific realms (Dumitriu et al. 2020). The Paratethys basin was a system of associated inland seas periodically subjected to partial or complete isolation from open sea waters (Kováč et al. 2017; Sant et al. 2017). In the middle Miocene, the Carpathian Foredeep experienced two marine transgressions interrupted by basin isolation events (Peryt 2006; de Leeuw et al. 2010).

\footnotetext{
${ }^{1}$ University of Gdańsk, Faculty of Oceanography and Geography, al. Marszałka Piłsudskiego 46, 81-378 Gdynia, Poland; e-mail: olga.reutt@wp.eu, ORCID: 0000-0003-0628-0552

${ }^{2}$ University of Gdańsk, Faculty of Oceanography and Geography, al. Marszałka Piłsudskiego 46, 81-378 Gdynia, Poland; e-mail: piotr.westphal@gmail.com, ORCID: 0000-0002-3832-2975
} 


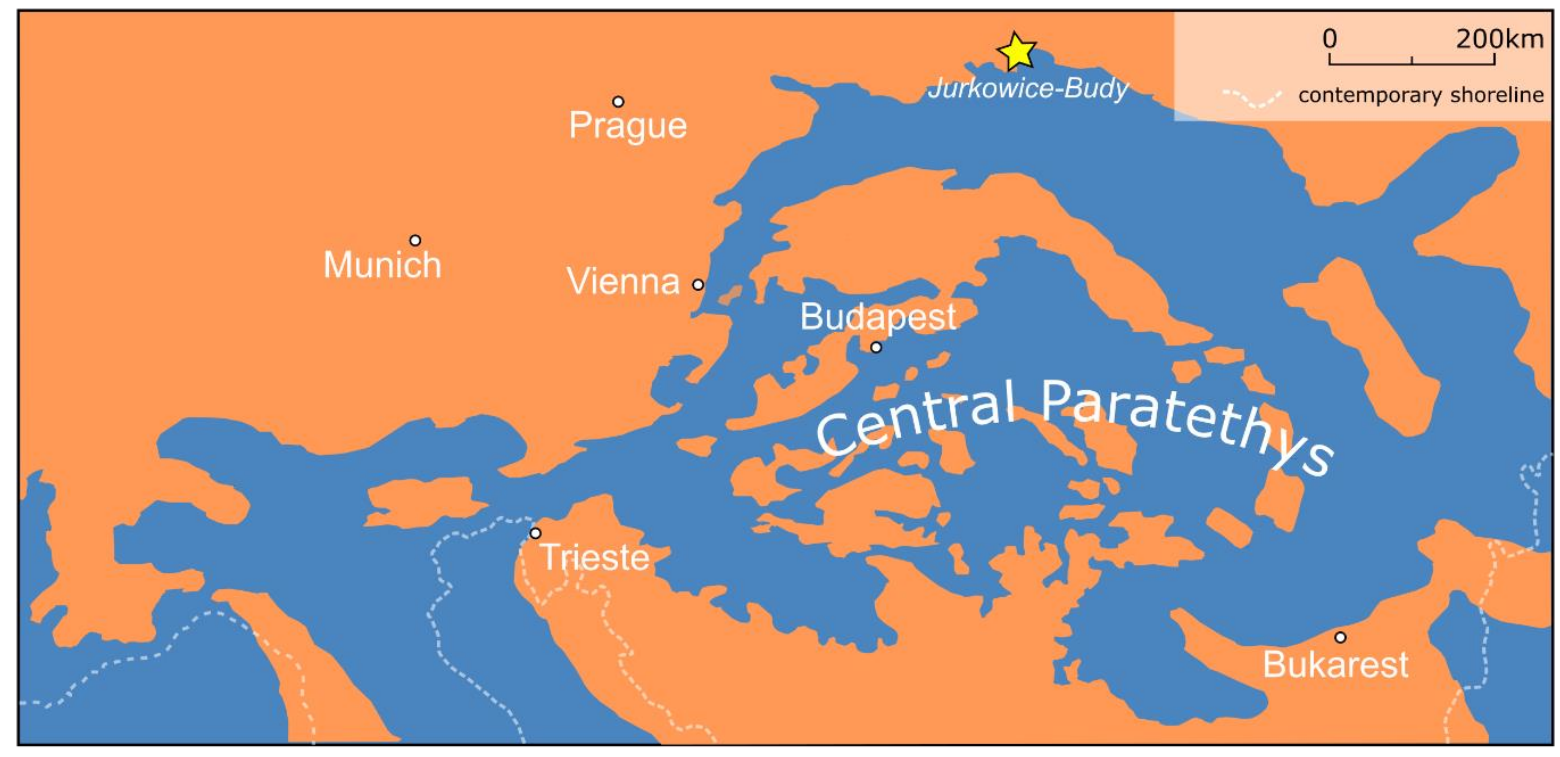

Fig. 1. Palaeogeographic reconstruction of the early Badenian (16.303-15.032 Ma) (Hohenegger et al. 2014) main transgression (modified after Hohenegger et al. 2009)

The shoreline configuration of the Paratethys Sea in SE Poland depended to a great extent on the pre-Miocene topography, where carbonate rocks of various ages (Devonian, Triassic, Jurassic) created a diversified shore with extensive bays, islands, cliffs and lagoons of Dalmatian character, while in the area of the Cambrian rock outcrops the coastline was of gently curved, beach-fringed outline (Radwański 1965, 1967, 1969, 1973). In the Jurkowice-Budy quarry, a mixture of both these configurations occur, since the weathering-resistant small Devonian belt formed the cliffs and the Cambrian rocks on the north and north-east was a sediment supply area for the sandy beaches that formed nearby.

This paper presents an attempt to reconstruct the pattern of environmental conditions with relation to the substratum and ancient coastal landforms, confronting them with conceptual models published earlier on. The deposits and littoral structures of the Jurkowice-Budy site are directly linked to the Paratethys transgression, which took place in relatively warm climate in that time (the Middle Miocene Climate Optimum) (see You et al. 2009). This preserved palaeocoast mostly represent major transgressive surfaces and may provide new insight into Paratethys sea levels as well as configuration and extent of ancient shoreline.

\section{Study site}

The Jurkowice-Budy quarry is located about $30 \mathrm{~km}$ west of Sandomierz on the southern margin of the
Holy Cross Mountains and bordering another major geological area, the Carpathian Foredeep (Fig. 2A). The quarry is dissected by a road; on the north side there is a smaller Jurkowice quarry and on the south side the Budy quarry (Figs. 2C, 3A). Together they form a business unit managed by "Kopalnie Dolomitu SA w Sandomierzu" which is one of the biggest dolomite and limestone quarries operating in the region.

Contact between Palaeozoic and Neogene units is clearly visible in the field (Sermet et al. 2016). The Palaeozoic profile consists of Cambrian (mudstones, siltstones, sandstones, shales), Silurian (siltstones) and Devonian (limestones, dolomitic limestones, dolomites) rocks that are exposed on the valley floors and in ravines (Romanek 1977). The Miocene deposits of the Jurkowice-Budy site are formed by sands, gravels and other calcareous sands or sandy-calcareous agglomerates (Romanek 1977). The finer deposits often fill the clefts of palaeocliffs.

\section{Methods}

In fieldwork carried out in April 2013 in the Jurkowice-Budy quarry, varied deposits were collected in four parts (A-D) of the quarry(Fig. 2C). Macroscopic observations and photographic documentation were made at each point, accompanied by a preliminary identification of the sediments. Gravels were analysed using methods by Cailleux (Cailleux, Tricart 1959) and Zingg (1935), and therefore it was decided to carry out the analysis 


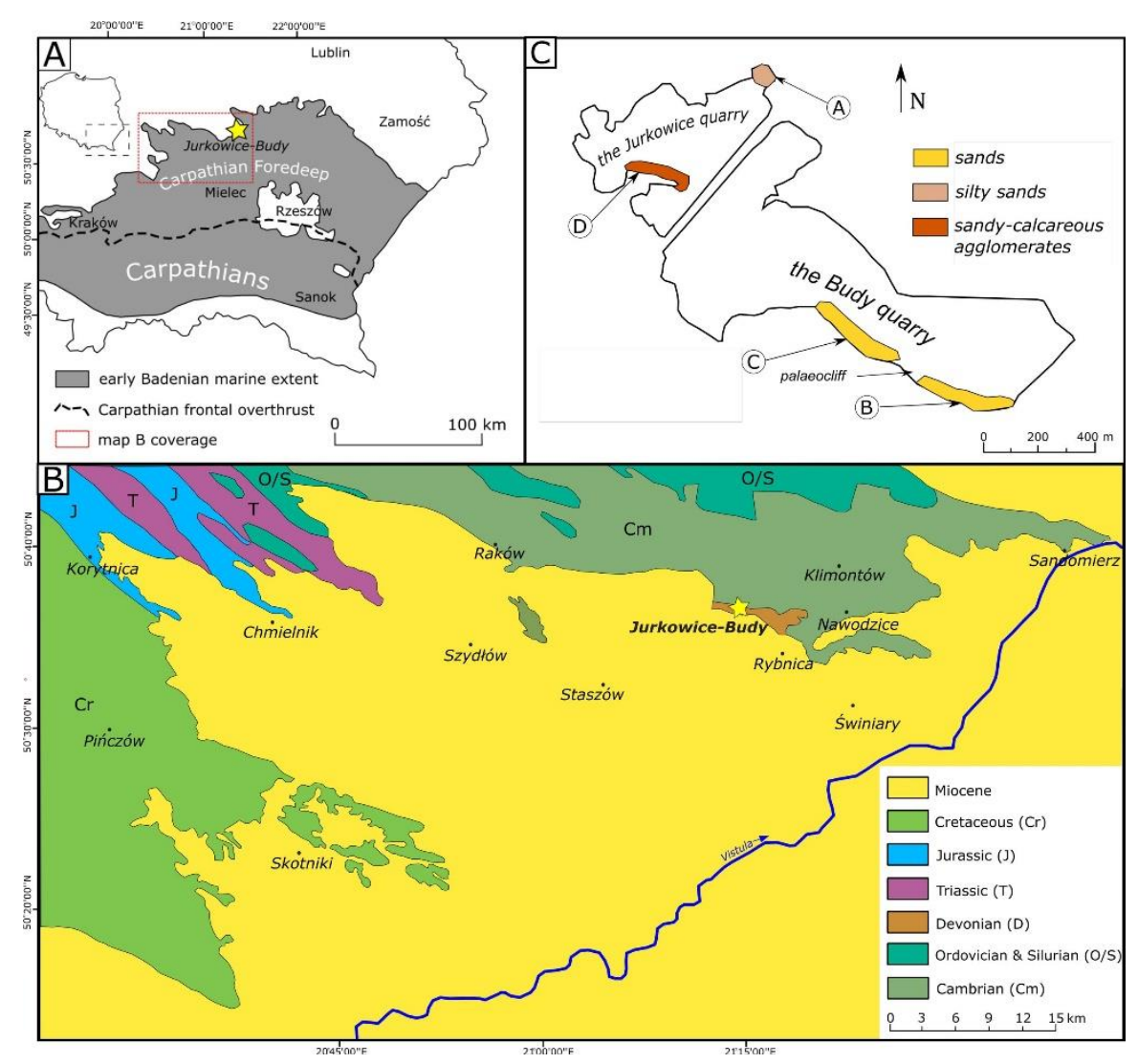

Fig. 2. Study area: A - Location of study area (according to Bukowski et al. 2018; modified);

B - Distribution of Miocene deposits on the southern and south-eastern slopes of the Holy Cross Mts. with its substratum (according to Radwański 1967; modified); C - Plan of quarry, showing parts A-D mentioned in text

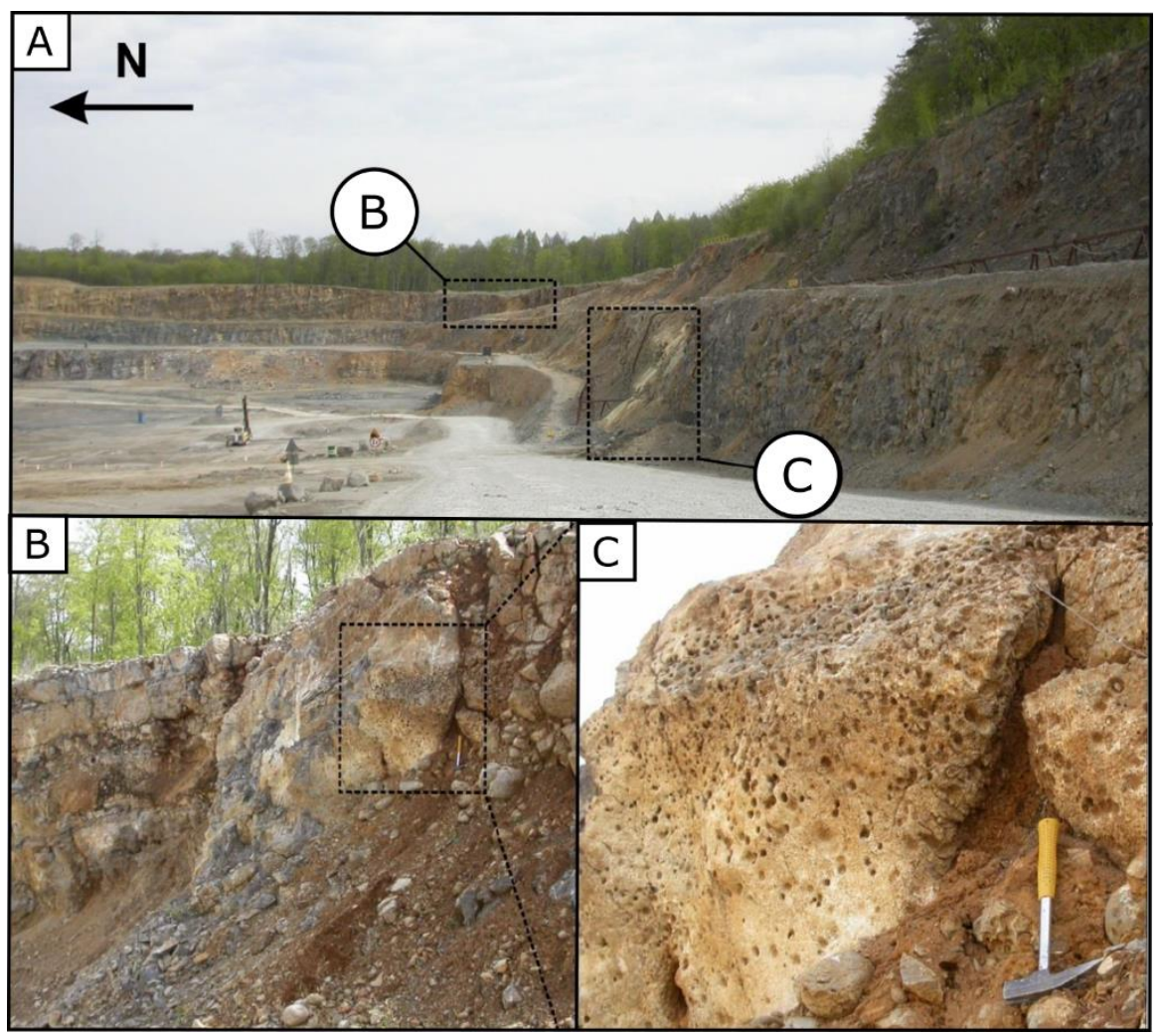

Fig. 3. The Budy quarry: A - General view of Budy quarry with parts B and C (see Fig. 2C); B - Cliff wall in part B; C - Detail of a cliff wall in part B sculptured by borings of lithophags; 30-cm hammer for scale 
in stages: (1) numbering on the surface to avoid errors; (2) measurements of three perpendicular geometrical axes on the pebbles using Vernier calliper, (3) determining the lithology, which in some cases required cracking pebbles in half. The grain-size analysis of the sandy deposits was conducted by the standard procedure of dry sieving; moreover, the silty deposits underwent wet sieving and grain-size analysis with the pipette method. The grain-size indices were calculated using methods of moments (Seward-Thompson,
Hails 1973) and the graphic procedure of Folk and Ward (1957). Statistical calculations are presented in Krumbein's $\varphi$ scale (Krumbein 1934; Krumbein, Sloss 1963). The final results were processed in MS Excel software.

\section{Results}

An overview of all collected samples is presented in Table 1.

Overview of collected samples

\begin{tabular}{|c|c|c|c|c|c|c|c|}
\hline $\begin{array}{l}\text { Part of } \\
\text { quarry }\end{array}$ & $\begin{array}{c}\text { Sediment } \\
\text { classification }\end{array}$ & $\begin{array}{l}\text { Sample } \\
\text { ID }\end{array}$ & Texture & Structure & Sorting & Colour & Lithology \\
\hline A & silty sands & $\begin{array}{c}\text { OL-1 } \\
\ldots \\
\text { OL-3 }\end{array}$ & coarse silt & massive & well sorted & white & $\begin{array}{c}\text { quartz (84\%), } \\
\text { barite (11\%) }\end{array}$ \\
\hline \multirow[t]{2}{*}{ B } & sands & $\begin{array}{c}\text { BU-6 } \\
\ldots \\
\text { BU-8 }\end{array}$ & $\begin{array}{l}\text { medium } \\
\text { sand }\end{array}$ & massive & well sorted & $\begin{array}{l}\text { light yellow } \\
\& \text { creamy- } \\
\text { white }\end{array}$ & quartz \\
\hline & gravels & $\mathrm{PBu} 2$ & pebbles & - & $\begin{array}{l}\text { not deter- } \\
\text { mined }\end{array}$ & $\begin{array}{l}\text { brownish \& } \\
\text { yellowish }\end{array}$ & quartz sandstone \\
\hline \multirow[t]{2}{*}{ C } & sands & $\begin{array}{c}\text { BU-1 } \\
\ldots \\
\text { BU-5 }\end{array}$ & $\begin{array}{l}\text { medium } \\
\text { sand }\end{array}$ & massive & well sorted & $\begin{array}{l}\text { light yellow } \\
\& \text { creamy- } \\
\text { white }\end{array}$ & quartz \\
\hline & gravels & PBu1 & pebbles & - & $\begin{array}{l}\text { not deter- } \\
\text { mined }\end{array}$ & $\begin{array}{c}\text { brownish \& } \\
\text { yellowish }\end{array}$ & quartz sandstone \\
\hline D & $\begin{array}{l}\text { calcareous } \\
\text { sands and } \\
\text { sandy-calcar- } \\
\text { eous agglom- } \\
\text { erates }\end{array}$ & $\begin{array}{c}\text { JU-1 } \\
\ldots \\
\text { JU-4 }\end{array}$ & coarse sand & massive & $\begin{array}{l}\text { poorly } \\
\text { sorted }\end{array}$ & dark yellow & $\begin{array}{l}\text { highly diversified: } \\
\text { quartz, dolomite and } \\
\text { gypsum grains, contains } \\
\text { organic fragments (e.g. } \\
\text { foraminifera shells) }\end{array}$ \\
\hline
\end{tabular}

\section{Silty sands}

In part A of the Jurkowice quarry, sediment samples were collected from an outcrop that was about $5 \mathrm{~m}$ high, $20 \mathrm{~m}$ wide and fringed by Devonian rocks on its east and west side (Fig. 4A, B). A sharp transition between very thick (around $5 \mathrm{~m}$ ), massive series of silty sediments and a thin layer (less than $1 \mathrm{~m}$ ) of Quaternary deposits is clearly visible. The wet sieving and pipette analysis helped to classify the deposits as "silty sands". Hence, the binocular analysis did not deliver a clear answer concerning the mineralogy composition, a XRF analysis was applied. The final results showed a major percentage of quartz $(84 \%)$ and an addition of barite $(11 \%)$.

\section{Sands}

A massive layer of sandy deposits in part B and C of the Budy quarry appeared between layers of gravel and in the direct vicinity of the cliff boulder masses (Fig. 5). These deposits were mineralogically composed of quartz grains only.

The result of granulometric analysis showed that the prevailing grain sizes are $0.25 \mathrm{~mm}$ (medium sand) and $0.125 \mathrm{~mm}$ (fine sand). In some samples, like BU-4 or BU-7, a relatively higher percentage of coarser fraction was noted, but it was caused by single pebbles, frequently of over $4 \mathrm{~mm}$ diameter, in the samples (Table 2). The sediments represent a median (M1) value of between 1.49 and 2.09 and a graphic mean size $\left(\mathrm{M}_{\mathrm{z}}\right)$ between 1.1 and 2.10. The sands are well sorted or moderately well sorted, ranging $0.5-0.6(\mathrm{M} 2)$.

Samples BU-4 and BU-7 were macroscopically classified as well sorted, but the calculated " $i$ " value reaches 1.04 and 1.01, which reflects "poorly sorted" sediments. This is because the dominating fraction is between $0.25 \mathrm{~mm}$ and $0.125 \mathrm{~mm}$, which increases the sorting index. However, summing up the percentage of those two fractions gives a result of over $90 \%$ in most 
cases, which demonstrates that these sands are very non-differential in their granulometric composition. Most of the sandy sediments are of negative skewness, which confirms that they are enriched with material of much coarser grain size (the aforementioned pebbles).

\section{Gravels}

The samples of gravels were collected from parts $\mathrm{B}$ and $\mathrm{C}$ of the Budy quarry (Fig. 6). The gravels ranged in size from $11 \mathrm{~mm}$ to $55 \mathrm{~mm}$ and therefore were classified as "pebbles". The samples' lithology was identified as quartz sandstone. The results of the measuring procedure were plotted into the Zingg diagram (Fig. 7), which showed that more than $50 \%$ of the pebbles are of disc shape.

Further analysis with the Cailleux method shows that $\mathrm{PBu} 2$ pebbles reach a higher flatness index, while $\mathrm{PBu} 1$ pebbles are of higher roundness index (Table 3). Moreover, all of the examined samples prove to be asymmetrical, with a mean asymmetry index of 0.7 for $\mathrm{PBu} 1$ and 0.68 for PBu2 (Table 3).

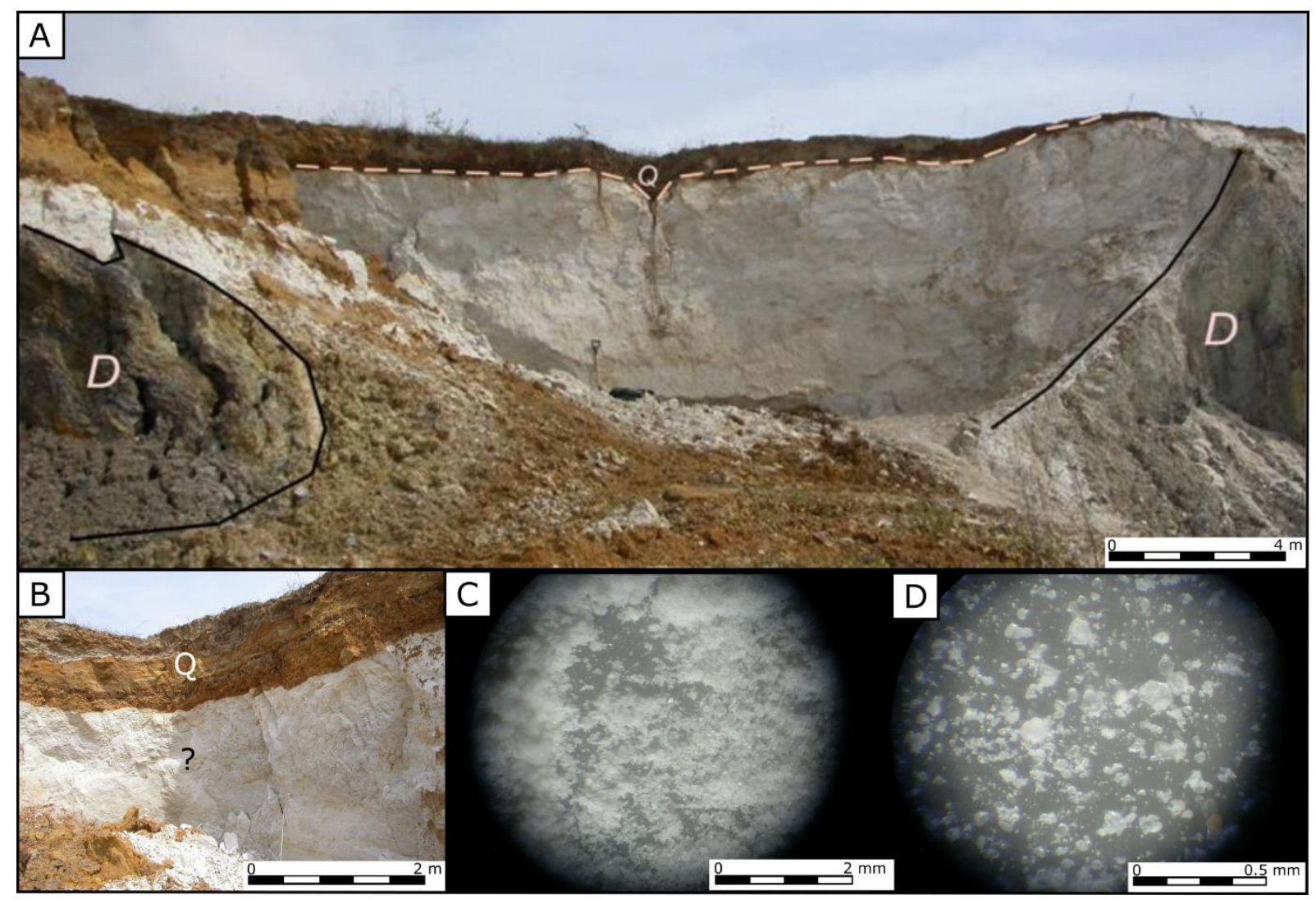

Fig. 4. A, B - Part A of the Jurkowice quarry and its sampling point.

C, D - Samples from part A under binocular microscope

D - Devonian dolomites, Q - Quaternary deposits

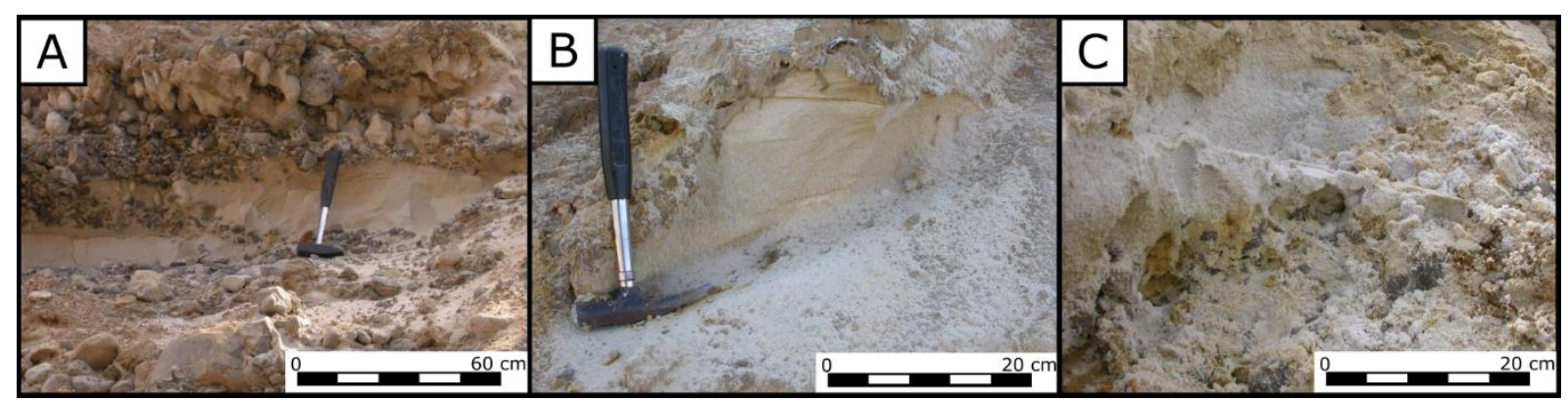

Fig. 5. A - Sandy deposits in part B of the Budy quarry; 30-cm hammer for scale; $\mathrm{B}, \mathrm{C}-$ Sandy deposits in part $\mathrm{C}$ of the Budy quarry 
Grain-size indices of sandy sediments

\begin{tabular}{|c|c|c|c|c|c|c|c|c|c|c|}
\hline Index & \multicolumn{8}{c|}{ Sample ID } \\
\hline & BU-1 & BU-2 & BU-3 & BU-4 & BU-5 & BU-6 & BU-7 & BU-8 \\
\hline \multicolumn{7}{|c|}{ Method of moments (Seward-Thompson, Hails 1973 ) } \\
\hline M1 & 2.09 & 2.03 & 1.86 & 1.55 & 1.89 & 1.93 & 1.49 & 2.08 \\
\hline $\mathrm{M} 2$ & 0.53 & 0.61 & 0.58 & 1.05 & 0.51 & 0.52 & 1.14 & 0.59 \\
\hline $\mathrm{M} 3$ & -0.23 & -1.19 & -0.88 & -0.74 & -0.01 & 0.06 & -1.66 & -1.92 \\
\hline $\mathrm{M} 4$ & 3.18 & 7.18 & 7.99 & 4.25 & 3.74 & 2.45 & 5.43 & 11.49 \\
\hline \multicolumn{7}{|c|}{ Folk and Ward's graphical method (1957) } \\
\hline $\begin{array}{c}\mathrm{M}_{\mathrm{z}} \\
\text { (graphic mean) }\end{array}$ & 2.09 & 2.05 & 1.88 & 1.61 & 1.89 & 1.93 & 1.75 & 2.10 \\
\hline $\begin{array}{c}\text { i } \\
\text { (inclusive graphic } \\
\text { standard deviation) }\end{array}$ & 0.61 & 0.63 & 0.61 & 1.04 & 0.61 & 0.61 & 1.01 & 0.61 \\
\hline $\begin{array}{c}\text { Sk } \\
\text { (inclusive graphic } \\
\text { skewness) }\end{array}$ & -0.14 & -0.12 & 0.17 & 0.16 & 0.16 & 0.11 & -0.15 & -0.17 \\
\hline $\begin{array}{c}\mathrm{K}_{\mathrm{G}} \\
\text { (graphic kurtosis) }\end{array}$ & 0.76 & 0.75 & 0.77 & 1.27 & 0.77 & 0.75 & 1.90 & 0.77 \\
\hline
\end{tabular}

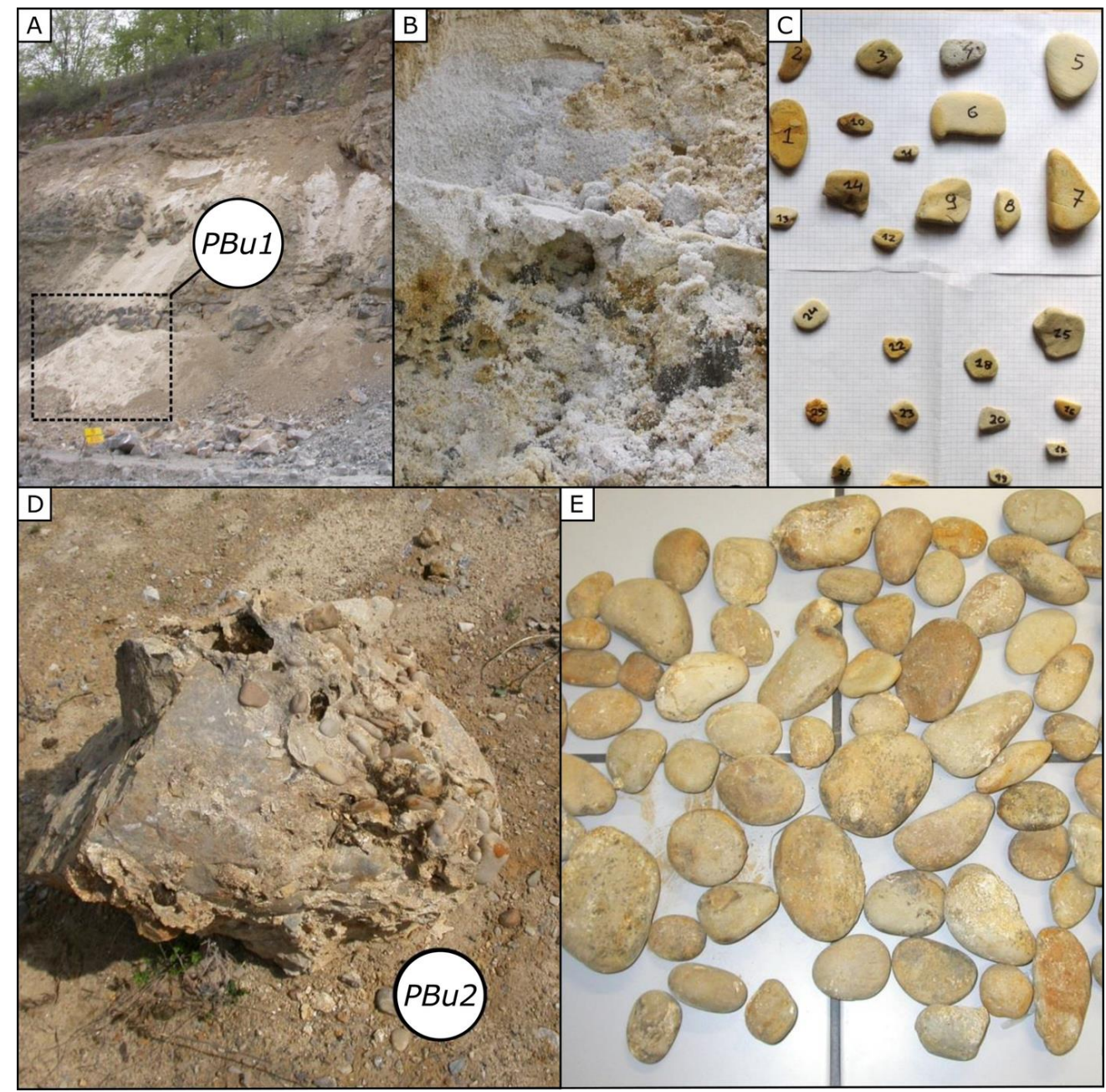

Fig. 6. A, B - Part C of the Budy quarry and its sampling point; $\mathrm{C}-$ Pebbles collected from part C (PBu1 samples); D - Part B of the Budy quarry and its sampling point; E - Pebbles collected from part $\mathrm{B}$ ( $\mathrm{PBu} 2$ samples) 


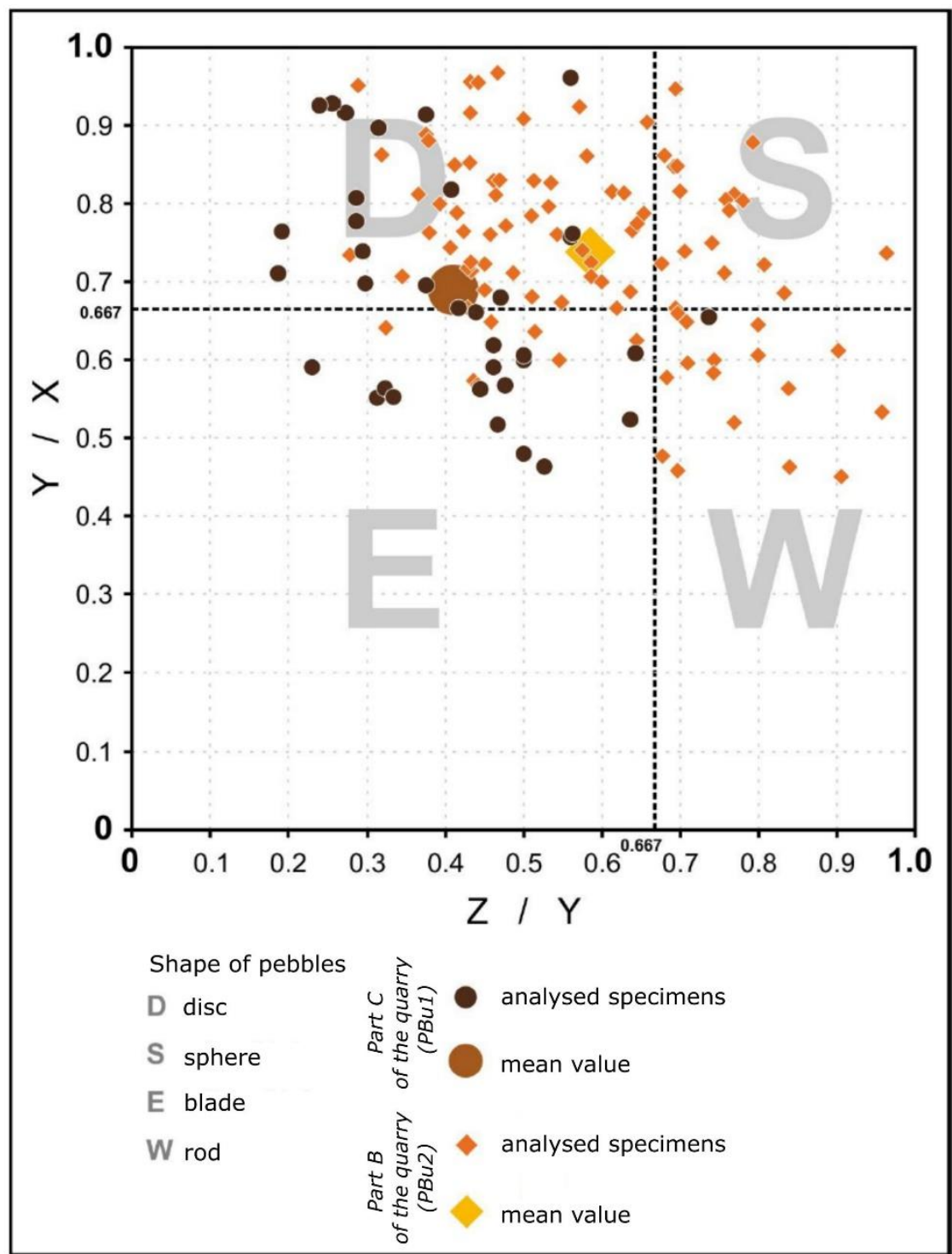

Fig. 7. Distribution of pebbles' shape from samples collected in parts $\mathrm{B}$ and $\mathrm{C}$ presented in Zingg diagram

Table 3

Results of measurements according to Cailleux method

\begin{tabular}{|r|c|c|c|c|}
\cline { 2 - 5 } \multicolumn{1}{c|}{} & \multicolumn{2}{c|}{$\begin{array}{c}\text { pebblesPBu1 } \\
\text { (part C of quarry) }\end{array}$} & \multicolumn{2}{c|}{$\begin{array}{c}\text { pebbles PBu2 } \\
\text { (part B of quarry) }\end{array}$} \\
\cline { 2 - 5 } & $\begin{array}{c}\mathrm{w}_{\mathrm{o}} \\
\text { (roundness index) }\end{array}$ & $\begin{array}{c}\mathrm{w}_{\mathrm{s}} \\
\text { (flatness index) }\end{array}$ & $\begin{array}{c}\mathrm{w}_{\mathrm{o}} \\
\text { (roundness index) }\end{array}$ & $\begin{array}{c}\mathrm{w}_{\mathrm{s}} \\
\text { (flatness index) }\end{array}$ \\
\hline minimum value & 0.05 & 1.71 & 0.09 & 1.22 \\
\hline maximum value & 0.38 & 6.42 & 0.53 & 2.25 \\
\hline mean value & 0.15 & 3.38 & 0.24 & 2.08 \\
\hline median & 0.13 & 3.08 & 0.24 & \\
\hline
\end{tabular}




\section{Calcareous sands and sandy-calcareous agglomerates}

In part D of the Jurkowice quarry, sediment samples were collected from an outcrop that was about $2 \mathrm{~m}$ high and $20 \mathrm{~m}$ wide (Fig. 8A, B). The deposits were identified as calcareous sands, creating spots of calcite-cemented bodies, which were examined later in the laboratory under bino- cular analysis and classified as sandy-calcareous agglomerates. Samples consist of grains that are highly differentiated in size and lithology mainly, poorly rounded grains of quartz, dolomite and, to a lesser extent, gypsum and others of undetermined mineralogy, with carbonate cement (Fig. 8C, E). Moreover, the sediments contain organic material - mainly, crushed fragments of shells (e.g., foraminifera shells).

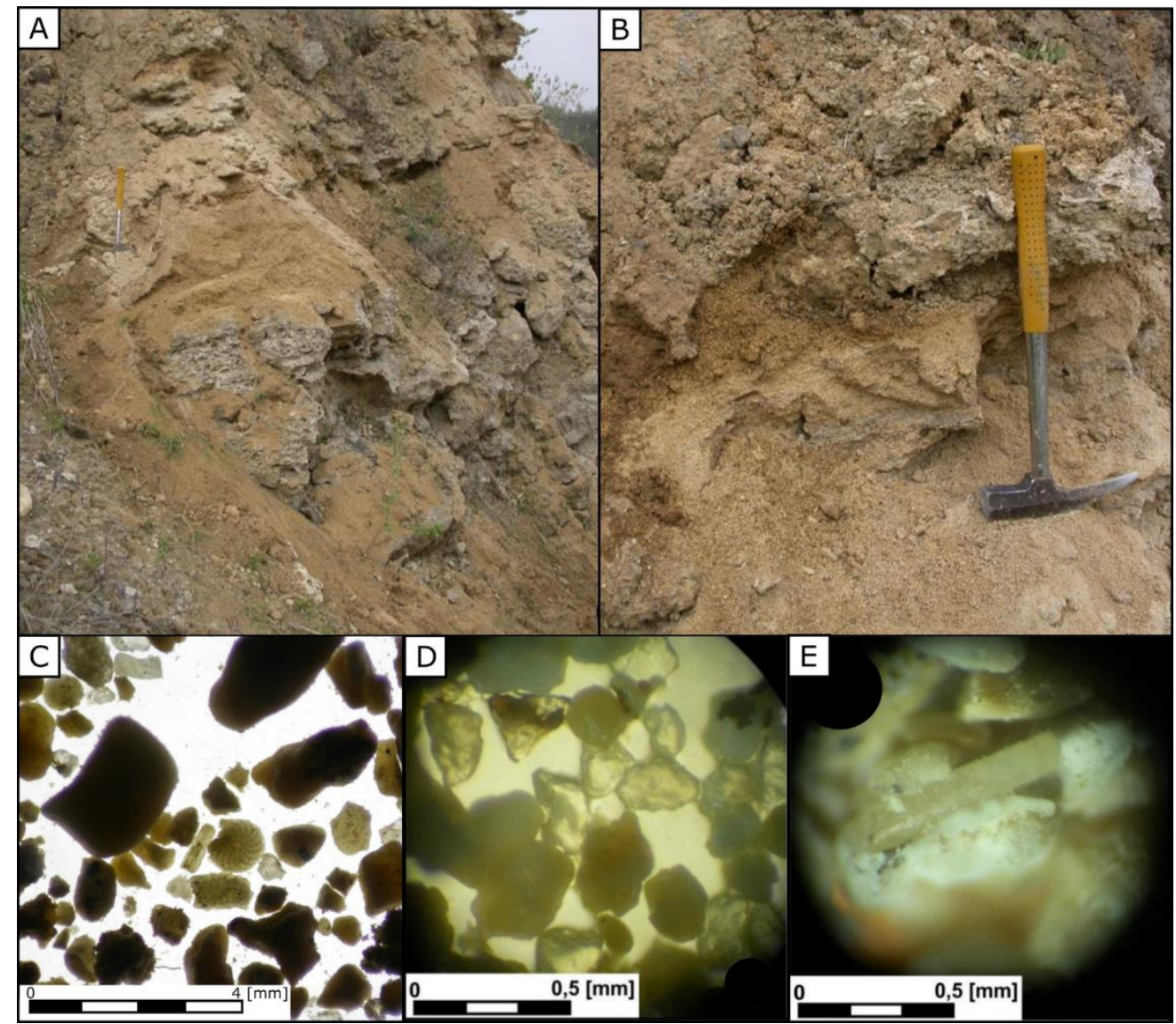

Fig. 8. Calcareous sands and sandy-calcareous agglomerates in part D of Jurkowice quarry:

A, B - Sampling points; $30-\mathrm{cm}$ hammer for scale; C-Various grains and foraminifera shell of calcareous sands; $\mathrm{D}$ - Poorly rounded quartz and other grains from sandy-calcareous agglomerates;

E - Gypsum grain from sandy-calcareous agglomerates

\section{Discussion}

Field studies allowed for a re-examination of some of the littoral structures that had previously been studied by Radwański (1965, 1967, 1969, 1973), who described boulder masses with boulders bored by bivalves of Lithophaga sp. species and others in the Jurkowice-Budy cliff. The borings of lithophags in the Devonian limestone found in part $\mathrm{C}$ of the quarry (Fig. 3B-C) is a crucial observation. These borings created bio-erosional assemblages, which have a higher preservation potential than any other component of a nearshore environment. That is why this finding undoubtedly determines the littoral nature of the examined deposits and it is reasonable to identify the outcropped wall as a palaeocliff.

Intense erosion of the hinterland produced some of the coarse sediments of Jurkowice-Budy. Pebbles of flattened shape (disc, blade and rod shape according to Zingg classification) represent $80 \%$ of the PBu2 samples and $97 \%$ of the PBu1 samples. These results coincide with findings of 
Jahn (1965), who examined beach pebbles of the Polish shore and concluded in her work that in well-developed beach assemblages flattened pebbles account for around 70-90\%. The extreme values of flatness index in Jahn's (1965) studies for sandstone pebbles of Baltic shore were 1.64-5.50 and corresponds with the Jurkowice-Budy pebbles ranging 1.71-6.42 (PBu1 - medium wave zone) and 1.22-4.25 (PBu2 - maximum wave zone). The source material (quartz sandstone) for detrital sediments is thought to be the Cambrian sandstones of the Klimontów area to the north of the study site, which corresponds to the studies of Rutkowski (1969) who examined the palaeotransport sediments between Chmielnik and Rybnica, later confirmed also by Czarniecka (2012).

The sandy deposits analysed here bear a strong resemblance to the lowest sedimentary set of unfossiliferous quartz sands (described in detail by Bałuk, Radwański [1968]) at Nawodzice, $4 \mathrm{~km}$ to the east of the study site. Concerning previous findings of the aforementioned authors and the granulometric characteristic of the sands, it is thought that those sediments might represent the transitional zone between sea and land (nearshore to beach environments), the source material originating from the intensively eroded Cambrian rocks in the north. The finer grains outflowed from the beach, leaving well sorted and massive sands. Since these sediments yield no fossils, it seems that strong waves and/or currents have cleared off any signs of marine life. Moreover, sands in the direct vicinity of the cliff boulder masses were presumably deposited in the cliff's clefts and/or erosional and tectonic dissections.

The nature of silty sands at the JurkowiceBudy site is full of uncertainty, since such fine quartz grains (Fig. 4C-D) are very rare in the coastal environment. The most probable scenario is that those deposits settled out of suspension in the calm waters of a lagoon sealed off from the sea (Davies, Fitzgerald 2020), but this does not explain their substantial thickness. However, the presence of barite suggests some sort of post-Badenian tectonic processes (see Czapowski 1976) that might also contribute to the thickness of the examined sediments. Barite in the form of aggregates occurred also in the fine-grained sands of Baranów Beds, a shallow water transgressive sandy facies found in Świniary, approx. $15 \mathrm{~km}$ south-east from the study area (Kenig, Wysocka 1996; Wysocka 1999; Radwański, Wysocka 2004).

We believe that our research, although limited in scope, may open future prospects for further studies focusing on analogues for modern shores, their biotic assemblages and environmental conditions. Moreover, the Polish Central Register of Geosites does not report in the region any site presenting an ancient rocky shore, so Jurkowice-Budy has geotourist potential, once the exploration in the quarry is complete.

\section{Conclusions}

(1) The study area documented some of Miocene nearshore zone sediments, including coarse sediments that were deposited in a relatively warm climate during the Badenian transgression onto the southern slopes of the Holy Cross Mts. The results of pebble analysis shows a well-developed beach assemblage, and the basic grain-size indices of sandy sediments suggest a beach-type sedimentation.

(2) The main source of clastic sediments of finer fraction was the Cambrian strata of quartz sandstones located in the north, while boulders, often with borings of lithophags, were isolated from the Devonian limestones and later accumulated in the form of autochthonous cliff boulder masses.

(3) The recognised sedimentary record involve beaches developed along eroded cliff walls, and possibly along different barrier structures (i.e. islands) and lagoons.

(4) Despite the limitations of the studies carried out, still it is worth noting that sediments and littoral structures of an ancient rocky shore were documented. This identification is believed to be important as it might serve as a reliable marker of a palaeoshoreline.

\section{Acknowledgments}

We would like to thank Tomasz Ciborowski for scientific guidance and providing us with the additional samples of deposits. We would also like to express gratitude to Piotr Woźniak, Damian Moskalewicz, Piotr Czubla and an anonymous reviewer, whose valuable suggestions improved the content of the manuscript.

\section{References}

Bałuk W., Radwański A. 1968. Dolnotortońskie piaski w Nawodzicach koło Klimontowa, ich fauna i wykształcenie facjalne. Acta Geologica Polonica 18: 446-464.

Bukowski K., Sant K., Pilarz M., Kuiper K., Garecka M. 2018. Radio-isotopic age and biostratigraphic position of a lower Badenian tuffite from the western Polish Carpathian Foredeep Basin 
(Cieszyn area). Geological Quarterly 62: 303318.

Cailleux A., Tricart J. 1959. Initiation à l'étude des sables et des galets. Centre de la documentation universitaire. Paris.

Czapowski G. 1976. Several kinds of carbonate cementations in Miocene sediments in the vicinity of Sandomierz (Holy Cross Mts., Central Poland). Bulletin de l'Académie Polonaise des Science. Série de Terre 24: 83-92.

Czarniecka U. 2012. Pochodzenie materiału ziarnowego w utworach ,sarmatu detrytycznego" (środkowy miocen) w północnej części basenu przedkarpackiego. PhD Thesis, University of Warsaw.

Davidson-Arnott R., Bauer B., Houser C. 2019. Introduction to Coastal Processes and Geomorphology. Cambridge University Press, Cambridge.

Davis R., Fitzgerald D. 2020. Beaches and coasts. John Wiley \& Sons, Oxford.

de Leeuw A., Bukowski K., Krijgsman W., Kuiper K.F. 2010. Age of the Badenian salinity crisis: Impact of Miocene climate variability on the circumMediterranean region. Geology 38: 715-718.

Dumitriu S., Dubicka Z., Loghin S., Melinte-Dobrinescu C., Paruch-Kulczyca J. 2020. The evolution of the Carpathian Foredeep Basin during the latest Badenian and Sarmatian (middle Miocene): inferences from micropalaeontological data. $\mathrm{Ge}$ ological Quarterly 64: 1004-1022.

Finkl C.W., Makowski C. 2019. Encyclopedia of coastal science. Springer International Publishing, Cham.

Folk R.L., Ward W.C. 1957. Brazos River bar: a study in the significance of grain size parameters. $\mathrm{Jo}_{\mathrm{O}}$ urnal of Sedimentary Petrology 27: 3-26.

Hohenegger J., Coric S., Wagreich M. 2014. Timing of the middle Miocene Badenian Stage of the Central Paratethys. Geologica Carpathica 65: 55-66.

Hohenegger J., Roegl F., Coric S., Pervesler P., Lirer F., Roetzel R., Scholger R., Stingl K. 2009. The Styrian Basin: A key to the middle Miocene (Badenian/Langhian) Central Paratethys transgressions. Austrian Journal of Earth Sciences 102: 102-132.

Jahn M. 1965. Otoczaki plażowe jako wskaźnik rozwoju brzegu morskiego. Acta Universitatis Wratislaviensis 39.

Johnson M. 1988. Why Are Ancient Rocky Shores so Uncommon? The Journal of Geology 96: 469480.

Kenig K., Wysocka A. 1996. Sand and calcite cement bodies (the Baranów Beds) from Świniary, eastern margin of Holy Cross Mountains.Geological Quarterly 40: 203-230.

Kováč M., Andreyeva-Grigorovich A., Bajraktarević Z., Brzobohatý R., Filipescu S., Fodor L., Harzhauser M., Nagymarosy A., Pavelić D., Rögl F., Saftić B., Sliva L., Studencka B. 2007. Badenian evolution of the Central Paratethys
Sea: Paleogeography, climate and eustatic sealevel changes. Geologica Carpathica 58: 579606.

Kováč M., Hudáčková N., Halásová E., Kováčová M., Holcová K., Oszczypko-Clowes M., Báldi K., Less G., Nagymarosy A., Ruman A., Klučiar T., Jamrich M. 2017. The Central Paratethys palaeoceanography: A water circulation model based on microfossil proxies, climate, and changes of depositional environment. Acta Geologica Slovaca 9: 75-114.

Krumbein W.C. 1934. Size frequency distribution of sediments. Journal of Sedimentary Petrology 4: 65-77.

Krumbein W.C., Sloss L.L. 1963. Stratigraphy and Sedimentation. W.H. Freeman \& Co., San Francisco.

Peryt T. M. 2006. The beginning, development and termination of the middle Miocene Badenian salinity crisis in Central Paratethys. Sedimentary Geology 188: 379-396.

Radwański A. 1965. Additional notes on Miocene litoral structures of southern Poland. Bulletin de l'Académie Polonaise des Sciences, Série des Sciences Géologiques et Géographiques 13. 167-173.

Radwański A. 1967. Problematyka mioceńskich struktur litoralnych na południowych stokach Gór Świętokrzyskich. Annales Societatis Geologorum Poloniae 37: 169-175.

Radwański A. 1968. Transgresja dolnego tortonu na obszarze Wyżyny Miechowskiej i Krakowskiej. Acta Geologica Polonica 18: 387-445.

Radwański A. 1969. Transgresja dolnego tortonu na południowych stokach Gór Świętokrzyskich (strefa zatok i przedpola). Acta Geologica Polonica 19: 1-164.

Radwański A. 1973. Transgresja dolnego tortonu na południowo-wschodnich i wschodnich stokach Gór Świętokrzyskich. Acta Geologica Polonica 23: 375-434.

Radwański A., Wysocka A. 2004. A farewell to Świniary sequence of mass-aggregated, spine-coated echinoids Psammechinus and their associates (middle Miocene; Holy Cross Mountains, Central Poland). Acta Geologica Polonica 54: 381399.

Romanek A. 1977. Objaśnienia do Szczegółowej mapy geologicznej Polski, arkusz Klimontów. Wyd. Geol., Warszawa.

Rutkowski J. 1969. Uwagi o sedymentacji detrytycznych osadów sarmatu na obrzeżu Gór Świętokrzyskich. Geological Quarterly 13: 177-182.

Sant K., Palcu D., Madic O., Krijgsman W. 2017. Changing seas in the early-middle Miocene of Central Europe: a Mediterranean approach to Paratethyan stratigraphy. Terra Nova 29: 273281.

Sermet E., Musiał A., Auguścik J. 2016. Geotourist attractions in the south-eastern part of the Holly 
Cross Mountains. Biuletyn Państwowego Instytutu Geologicznego 466: 271-278.

Seward-Thompson B., Hails J. 1973. An appraisal of the computation of statistical parameters in grain size analysis. Sedimentology 20: 161-169.

Wysocka A. 1999. Depositional and tectonic controls on Early Badenian clastic sedimentation in the Sandomierz-Tarnobrzeg area (Baranów Beds, northern Carpathian Foredeep). Geological Quarterly 43: 383-394.
You Y., Huber M., Müller R., Poulsen C., Ribbe J. 2009. Simulation of the middle Miocene Climate Optimum. Geophysical Research Letters 36 (4): $1-5$.

Zingg T. 1935. Beitragzur Schotteranalyse. Schweizerische mineralogische und petrographische Mitteilungen, Zürich. 